DOI https://doi.org/10.30525/978-9934-26-109-1-7

\title{
MODIFICATION OF REPAIR COATINGS BY INPUTTING A NATURAL COMPONENT - CLAY
}

\author{
Rybalko I. M. \\ Candidate of Technical Sciences, \\ Senior Lecturer of the Department of technological systems \\ of repair production \\ Kharkiv Petro Vasylenko National Technical University of Agriculture
}

\author{
Skoblo T. S. \\ Doctor of Technical Sciences, \\ Professor of the Department of technological systems of repair production \\ Kharkiv Petro Vasylenko National Technical University of Agriculture \\ Kharkiv, Ukraine
}

The purpose of the research was to investigate the possibility of using natural raw materials - bentonite clay - to modify the clad metal coating.

The most effective modifying additive is bentonite clay with a finegrained powder fraction $[1 ; 2]$. Its influence on changing the structural state of the surface of cultivator tines during surfacing can contribute to an increase in wear resistance, especially considering the fact that the components and their compounds in it are in the soil with which these products work and they are close in composition. When selecting such a natural substance for the modification, it was assumed that its admixture is available for usage and it includes increased $\mathrm{Si}$ and $\mathrm{Al}$ content and these components are partially in compounds with oxygen $\left(\mathrm{SiO}_{2}\right.$ and $\left.\mathrm{Al}_{2} \mathrm{O}_{3}\right)$. In the particular case under consideration, the chemical composition of bentonite clay has, in percentage correlation: $1.65 \mathrm{Fe}$; $0.25 \mathrm{~K} ; 0.15 \mathrm{Ca}$; $0.06 \mathrm{~S} ; 0.2 \mathrm{Mn} ; 54.88 \mathrm{Si} ; 32.42 \mathrm{Al} ; 0.3 \mathrm{Na} ; 0.2 \mathrm{Mg}$.

Considering the fact that the most effective modifying additive of such admixture, which is $5-7 \%$ of the electrode share, it will be as follows, in percentage correlation: $0,10 \mathrm{Fe} ; 0,02 \mathrm{~K} ; 0,01 \mathrm{Ca} ; 0,004 \mathrm{~S} ; 0,012 \mathrm{Mn}$; $3,3 \mathrm{Si} ; 1,95 \mathrm{Al}$. With a decrease in the share of its addition in the coating, the effect of modification is significantly reduced, because the carbide phase in the arc deposition is not evenly crushed, as well as the grain size changes only in local areas. The increase in the share of admixture (>10-12\%) leads to the appearance and growth of complex nonmetallic 
inclusions, which reduces the quality of the coating. In this case, microhardness inhomogeneity also occurs.

Arc deposition coatings in both cases form a martensite structure (Fig. 1).

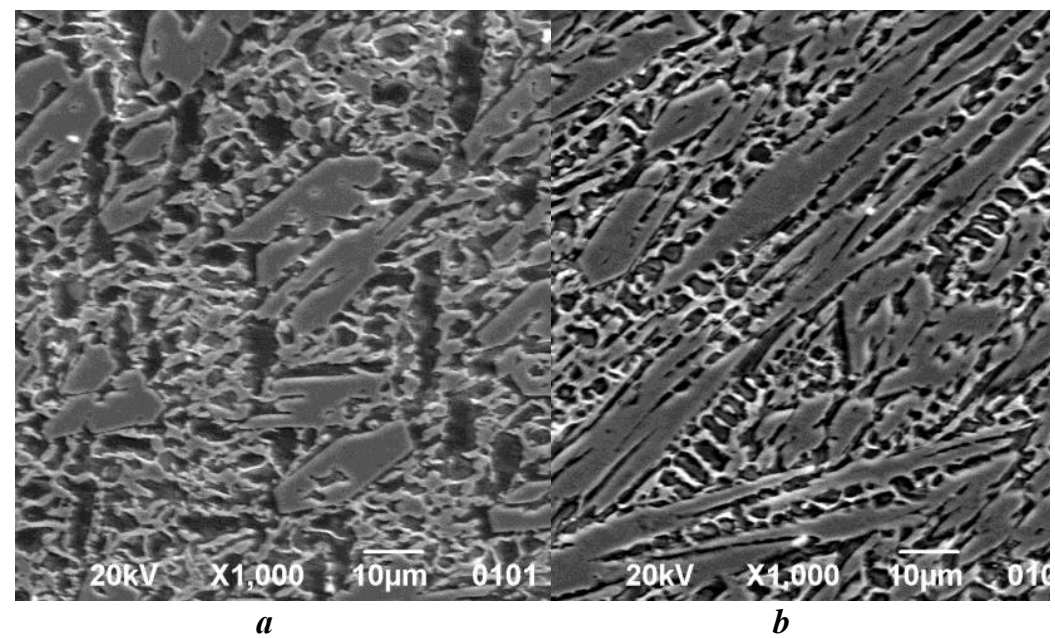

Fig. 1 The formed structure during arc deposition: $a$ - with electrode; $b$ - with additional modification with clay

To use this modifying additive it was dried at $\mathrm{t}=240^{\circ} \mathrm{C}$ and then milled in a ball mill to a grain size of 40-50 microns for 2 hours. After that, glue was added to the powder, stirred and applied to the electrode, dried at $\mathrm{t}=$ $180^{\circ} \mathrm{C}$, and then used to form the coating by arc deposition.

It is established that such technological process of modification provides the change in structure formation. The carbide phase is crushed, it is distributed more evenly and its share increases by $30 \%$, the transition zone and thermal influence decrease by 40 and $30 \%$ respectively, and the degree of penetration of thin-walled cultivator tines decreases and is only $60 \%$, while without modification with clay its damageability is noted.

Microhardness also changes slightly due to such modification (fig. 2). Itwas established that irrespective of measurements direction - crosswise or longitudinal (was estimated on diagonals of prints) at optimal modification microhardness is more uniform and changes in coating from H-50-671,6 (matrix) and to H-50-1193,9 (carbides), and without modification from H-50-686,1 to H-50-1283,3 respectively. The high level 
of microhardness in an initial condition of a covering (without modification) corresponds to a transition zone and is connected with that contains the most part of rough inclusions of a carbide phase in this variant and defines change of indicators, and also depends on exertion level. The total share of the crushed carbide inclusions increases with clay modification. Their share increases by $20 \%$ due to decrease of fluid bath temperature during coating with modifying additive. We analyzed the composition in the hardened, reduced layer and evaluated the local distribution of components included in the modifying additive and T-620 electrode (chemical composition, in percentage correlation: $3.0 \mathrm{C} ; 2.2 \mathrm{Si}$; 1.2 Mn; 22.5 Cr; 0.7 Te; 0.8 B; 0.03 S).

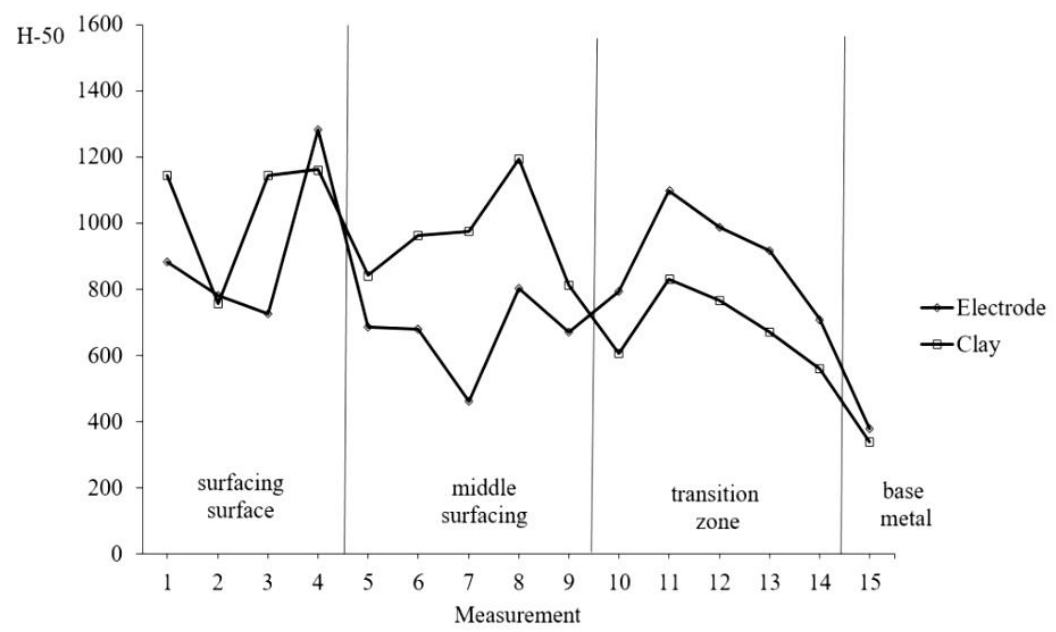

Fig. 2 Change of microhardness according to the depth of coating: $a$-with electrode $T-620 ; b$ - with additional input of bentonite clay

It is found that carbon, $\mathrm{Ti}, \mathrm{Ca}, \mathrm{Al}$ are distributed quite evenly, $\mathrm{Cr}$ is detected only in the structurally free carbide phases, and Mo, Mn in the matrix phase. The largest share of $\mathrm{Si}$ is concentrated in the matrix phase, and this component is also distributed in the more massive inclusions of chromium carbides (divides them into separate fragments and they become thinner). Iron is not detected in chromium carbides, so they can be attributed to inclusions $\mathrm{Cr}_{7} \mathrm{C}_{3}$ (eutectic), and matrix to $\mathrm{Cr}_{23} \mathrm{C}_{6}$. The distribution of oxygen is heterogeneous, but, as shown by local spectral microanalysis, its share does not exceed $15.98 \%$. 
It was also necessary to establish the strength of the connection between the coating and the base metal in order to use such a modifying additive. The evaluation was carried out using the microhardness measurement method, where it was shown that a load of even up to $1 \mathrm{~kg}$ on the indenter did not contribute to the damage of the connection. This can be explained by the fact that during modification the stresses in the boundary transition layer of the coating also decrease. Table 1 shows the results of bench wear tests, which show that the wear coefficient is 2.2 times lower in comparison with the original steel $65 \mathrm{G}$ and 1.4 times lower in relation to arc deposition with only electrode T-620 [3].

Table 1

Wear resistance test under abrasive conditions

\begin{tabular}{|c|l|c|}
\hline $\begin{array}{r}\text { № } \\
\text { n/a }\end{array}$ & \multicolumn{1}{|c|}{ Strengthening option } & Wear rate \\
\hline 1 & Initial material cultivator tines steel 65G & 1.0 \\
\hline 2 & Arc deposition with T-620 electrode & 0.62 \\
\hline 3 & $\begin{array}{l}\text { Arc deposition with T-620 electrode with additional } \\
\text { modification of bentonitic clay (5-7\%) }\end{array}$ & 0.45 \\
\hline
\end{tabular}

Based on the obtained results of modifying the restorative coating with a natural component - bentonite clay, it is characterized by increased properties, which allows to significantly reduce the costs of using modifiers in production. Such a charge is available for usage by small enterprises when restoring parts, especially those who work with soil.

The proposed technological process of modification provides a change and structure formation, the carbide phase is crushed and distributed more evenly and its proportion increases by $30 \%$, the transition zone and thermal influence decreases by 40 and $30 \%$ respectively, and the degree of penetration of thin-walled cultivator tine decreases and is only $60 \%$.

At optimum modification with $5-7 \%$ bentonite clay microhardness is more homogeneous and varies in coating from H-50-671,6 (matrix) and up to H-50-1193,9 (carbides). Technical field tests determined that the wear coefficient is 2.2 times lower compared to the original steel $65 \mathrm{G}$ and 1.4 times lower in relation to arc deposition only with electrode T-620. 


\section{References:}

1. Применение модифицирующей присадки - глины при восстановительной наплавке деталей / Т.С. Скобло, И.Н. Рыбалко, А.И. Сидашенко, А.В. Тихонов. Сварочное производство. 2020. № 7. С. 41-49.

2. Спосіб підвищення якості та експлуатаційної стійкості відновлюючих покриттів їх модифікуванням маловитратною домішкою: пат. 147660 Україна: МПК С23С 4/131 (2016.01). № 2020 08115. заявл. 18.12.2020. опубл. 02.06.2021. Бюл. № 22. 4 c.

3. Improving the wear resistance of hoe blades by modifying of restoration coatings / T.S. Skoblo, I.N. Rybalko, A.V. Tihonov, T.V. Maltsev. Problems of Tribology. 2019.94 (4). P. 27-31. 